\title{
Job Satisfaction, Motivation and Commitment to Change of Stated Owned Enterprises Ministry Employee of Indonesia
}

\author{
Umi Gita Nugraheni ${ }^{1}$, Aji Hermawan ${ }^{1}$, \& Sadikin Kuswanto ${ }^{1}$ \\ ${ }^{1}$ School of Business, Bogor Agricultural University, Bogor, West Java, Indonesia \\ Correspondence: Umi Gita Nugraheni, School of Business, Bogor Agricultural University, Jl. Raya Padjajaran, \\ Bogor, West Java, Indonesia. Tel: 62-821-2317-9417. E-mail: umigita@gmail.com
}

Received: February 21, 2019

Accepted: March 6, 2019

Online Published: March 29, 2019

doi:10.5539/ass.v15n4p94

URL: https://doi.org/10.5539/ass.v15n4p94

\begin{abstract}
The State-Owned Enterprises Ministry as one of the Government agencies has a strategic role as a builder of State-Owned Enterprises to change the form of organizational bureaucracy and transformation to be a superholding company. This study focused on the influence of internal factors namely employee motivation and job satisfaction toward the commitment to change of State-Owned Enterprises Ministry employee.

This study aimed to find out whether the motivation and job satisfaction affect the commitment to change, as well as provide strategies to increase commitment to succeed employee's change toward the organizational changes. Data were collected using a stratified random sampling of 177 State-Owned Enterprises Ministry employees by spreading questionnaire, in-depth interviews with management, and focus group discussion (FGD) with the representatives of the employees from each division.

The results indicated that motivation significantly associated with job satisfaction and Job Satisfaction is associated with the higher level of employees commitment to Change, but motivation was not associated with commitment to change. Qualitatively, it was more due to the change of commitment form among employees of the Ministry of State-Owned Enterprises, in General, it is a normative commitment and the commitment of the continuance, where employees feel obligated to support organizational change, not to take the effective role to make changes to the organization. Cross-validation result indicated that the final full SEM was valid and reliable.
\end{abstract}

Keywords: commitment to change, motivation, job satisfaction, organizational change

\section{Introduction}

Organizational transformation means doing things in new ways, applying new system, adopting new technology, producing a brand new management system, merging, reorganizing, and doing the whole disruptive and significant shebang (Davidson, 2005). Organizational transformation is encouraged by the new technology, merger or acquisition, restructuration, new strategies, the transformation of organizational culture, and globalization (Kotter, 2002).

Cunningham (2016) stated that research on organizational transformation has been conducted in a great numbers either focusing on external or internal factors, on organizational strategy, or on individual factors which focus on organization leader level, such as transformational leadership, change leadership and team management. However, research on micro things of employee's behavior that support organizational change is still deficient.

Bureaucracy Reformation is Indonesia Government programme that should be implemented by any bureaucratic system, including State-Owned Enterprises Ministry. The bureaucratic reform in the 2014-2019 period becomes the elaboration of Indonesia "Nawacita" making the government always present as transparent, fair, democratic, and reliable governance." In accordance with the Grand Design of Indonesian Bureaucratic Reformation in 2010-2015, Bureaucratic Reformation was interpreted as a major change of the paradigm and governance of government that leads to organizations (institutions), management, human resources, services, accountability, legislation and mindset.

Furthermore, as the strategic planning of State-Owned Enterprises Ministry, the ideal formation of State-Owned Enterprises Ministry organization is still debated whether institution for managing state-owned enterprises as high as ministry level is required or forming superholding company as the "umbrella" manager for state-owned 
enterprises in order to drive the values creation process for the greatest interest of the wider community.

Mangundjaya (2013) explained that organization transformation gets effected by many things, started from the employee factors, like employee commitment to change. Herscovitch and Meyer (2002) stated that commitment to change was the key point to implement transformation. Commitment to change defined as a binding between mindset and action to implement the transformation. According to Shum et al. (2008), if each member of the organization has a commitment to change, the transformation will be successfully applied. There are some factors influencing the commitment to change, internal and external factors (Mangundjaya, 2016). The internal factors are belief, personal concern, motivation, roles autonomy, organization commitment, personal vision and strategies, and individual readiness to change (Parish et al., 2008). On the other hand, the external factors are organization fairness, leader support, communication to change, believe to the organization, participation in decision making, the relationship between leaders and subordinates, and leadership (Mangundjaya, 2016).

Besides the factors above, there is another factor which is significantly affected the form of commitment to change, job satisfaction. Yousef (1998) in his research proved that job satisfaction was a predictor that supported organizational transformation with a commitment to change as the mediator variable. Hence, Mangunjaya (2015) stated that job satisfaction significantly influenced to the commitment to change. Job satisfaction is also mediator variable between change leadership and the commitment to change (Wulandari et al., 2015).

\subsection{Research Objectives}

The research objectives are as follows:

1. Organizational transformation in State-Owned Enterprises Ministry is an urge to put action on that now research and negotiations between government institution has been started.

2. Organization transformation needs the commitment to change from all employees, moreover this transformation is continuing until the years to come.

3. It is important to know how employee motivation, job satisfaction, and organizational commitment of SOE Ministry employee to support the organizational transformation.

\section{Literature Review}

\subsection{Commitment to Change}

Commitment to change theory by Herscovitch and Meyer (2002) defines commitment as a drive (mindset) that bind people to do a series of activities for change initiatives. Commitment to change initiative includes three dimensions, namely; 1) affective commitment (employee' desire to support organizational transformation because of its benefits for the individual or to organization), 2) continuance commitment (employee' desire to support organizational change because of cost individual will get for leaving), and 3) Normative commitment (employee's desire to support the organization because of feeling obligated to support the transformation, this commitment develops through social interaction and the feeling to return (payback) what they got from the organization.

\subsection{Job Satisfaction}

Spector (1997) defined job satisfaction as what the employees feel about their job and other aspects from their job. Job satisfaction is a measurement to assess how satisfied and dissatisfied employees with their work are.

Table 1. Job Satisfaction Survey based on Spector (1997)

\begin{tabular}{ll}
\hline Aspects & Descriptions \\
\hline Salary & Satisfaction with salaries and salary increases \\
Promotion & Satisfaction with the opportunities for promotion and the fairness in promotion \\
Supervision & Satisfaction with the supervisor or the assignment given \\
Fringe Benefits & Satisfaction with the benefits provided in the form of insurance, facilities, etc \\
Reward & Satisfaction with rewards (not only in the form of money) for good performance \\
Working rules and procedures & Satisfaction with working rules and procedures applied \\
Co-workers & Satisfaction with the co-workers \\
Profession & Satisfaction with the profession and the type of work \\
Communication & Satisfaction with the communication style in the organization \\
\hline
\end{tabular}




\subsection{Motivation}

There are a lot of theories that explained about employees motivation, but the theory that significantly related to job satisfaction is Two Factors theory or Hygene motivation theory by Herzberg. Herzberg stated that thing that evoked motivation (intrinsic) were an opportunity to make an achievement, a recognition, work to do, responsibility, and development (Robbins \& Judge, 2013). Furthermore, Herzberg (in Robbins \& Judge, 2013) explained that there were hygene factors known as the external reward or extrinsic factors, which were not considered as sources of motivation because it provided convenience. Those factors are supervision quality, working space, salary, organizational rules, and working relationship.

Some studies were conducted to see the relationship between these variables, Hercovits and Meyer (2002) stated that commitment to change was the continuance of organizational commitment, and it pointed to the specific organizational change. This study showed that commitment to change was a better behavioral predictor than organizational commitment. Commitment to change as the affective commitment and the normative commitment is more influencing than the continuous commitment. Meanwhile, Elias (2007) conducted a research about motivation and commitment to change, and it revealed that motivation was an anticedent of affective commitment toward commitment to change, even though the variable should be moderated with behavior variable to get to the importance of organizatinal change. It is also in accordance with Parish et al. (2008) study, that stated that motivation was influencing commitment to change.

Mangunjaya (2015) revealed that job satisfaction positively influence with one of commitment dimension, that is the effective commitment to transformation. Furthermore, Wulandari (2015) acknowledged job satisfaction as the mediator variable between change leadership and commitment to change.

\subsection{Research Hypotheses}

Table 2. Research model, independent and dependent variable

\begin{tabular}{ccc}
\hline Model & Independent Variable & Dependent Variable \\
\hline Model 1 & Motivation & Job satisfaction \\
Model 2 & Motivation & Commitment to Change \\
Model 3 & Job Satisfaction & Commitment to Change \\
\hline
\end{tabular}

This study used hypothesis Testing design to find the initial guess or conclusion, and the hypotheses are:

1. Hypothesis 1 (H1): Motivation influence job satisfaction;

2. Hypothesis 2 (H2): Motivation influence commitment to change;

3. Hypothesis $3(\mathrm{H} 3)$ : Job satisfaction influence commitment to change.

\section{Research Methodology}

The population of this study was the State-Owned Enterprises Ministry employees in Jakarta, Indonesia. This Ministry has 297 employees, and 177 employees were determined by using Slovin abbreviation (Sumarwan, 2008). The research sample was 177 SOE Ministry employees that was selected by using stratified random sampling. The data were collected using a Likert questionnaire, In-depth Interview with the management division, and focus group discussion (FGD) was conducted to get in depth information from the employee. The questionnaire consists of three sections, section one concern motivation used based on intrinsic motivation factor and hygene by Herzberg scale, it assessed employees opportunities for achievement, recognition, work, responsibility, development, quality of leadership supervision, salary, organizational rules, physical conditions of work and working relationship.

Section two concern job satisfaction and was based on Spectors (1997) survey, which measured employees satisfaction with salary, promotion, supervision, fringe benefits, reward, working rules and procedures, co-workers, work, and the communication. The last section is changed commitment assessed based on Hercovits and Meyer (2002) scale, which consist of affective commitment to change, continues commitment to change, and normative commitment to change.

The model used in this study is an adaptation from previous studies or from the existing theory (SEM). The nature of SEM itself is to confirm existing theories or models, SEM should not use the newly formed model. Each latent variable has a reflective type indicator which will be a measure in the analysis of research data. 


\subsection{Variable Loading Factors}

Confimratory Factor Analysis (CFA) was conducted to know the variable loading factors. Hair et al. (2014), explained that CFA is the part of SEM (Structural Equation Modeling) used to examine how well the indicators in representing the factors or constract. Constract is an immeasurable variable that requires measurable variables (indicators) to be able to describe the constract.

Besides, CFA also used to examine the affirmation of the measurement theory. Measurement theory used to determined how measureable variables could describe the constract logically and sistematically. CFA indicator be avowed as valid indicator if Standardized Factor Loading (SFL) > 0,50 (Igbaria et al., 1997). Invalid indicator will not be included for further estimatimation.

Table 3. Variable Loading Factors

\begin{tabular}{|c|c|c|}
\hline Latent Variable Level 2 & Standardized Factor Loading (SFL) & Latent Variable Level 1 \\
\hline \multirow{10}{*}{ Motivation (X1) } & 0.88 & Opportunities for achievement (X1.1) \\
\hline & 0.81 & Recognition (X1.2) \\
\hline & 0.91 & Work (X1.3) \\
\hline & 0.83 & Responsibility (X1.4) \\
\hline & 0.92 & Development (X1.5) \\
\hline & 0.91 & Quality of leadership supervision (X1.6) \\
\hline & 0.87 & Salary (X1.7) \\
\hline & 0.93 & Organization Rules (X1.8) \\
\hline & 0.82 & Physical conditions of work (X1.9) \\
\hline & 0.90 & Working relationship (X1.10) \\
\hline \multirow{9}{*}{ Job Satisfaction (X2) } & 0.90 & Salary (X2.1) \\
\hline & 0.74 & Promotion (X2.2) \\
\hline & 0.87 & Supervision $(\mathrm{X} 2.3)$ \\
\hline & 0.89 & Fringe Benefits (X2.4) \\
\hline & 0.95 & Reward (X2.5) \\
\hline & 0.85 & Working Rules and Procedures (X2.6) \\
\hline & 0.92 & Co-Workers (X2.7) \\
\hline & 0.93 & Work (X2.8) \\
\hline & 0.97 & Communication (X2.9) \\
\hline \multirow{3}{*}{ Commitment to change (Y) } & 0.93 & Affective commitment (Y.1) \\
\hline & 0.98 & Normative commitment (Y.2) \\
\hline & 0.98 & Continuans commitment (Y.3) \\
\hline
\end{tabular}

Based on the result above, all SFL $>0.50$, which means each indicators in the questionair is able to measure its dimention and all dimention able to examine independent and dependent variable.

\subsection{Validity and Reability}

Validity and reliability of the construct were examined using variance extracted (VE) and construct reliability (CR). The result showed that the construct is valid and reliable. the value was $\mathrm{VE} \geq 0.5$ and $C R \geq 0.7$.

Table 4. Value of VE and CR

\begin{tabular}{lccc}
\hline & Latent Variable & VE & CR \\
\hline Motivation (X1) & 0.86 & 0.98 \\
\hline
\end{tabular}




\begin{tabular}{|c|c|c|c|}
\hline - & Opportunities for achievement (X1.1) & 0.77 & 0.87 \\
\hline- & Recognition (X1.2) & 0.79 & 0.82 \\
\hline - & Work (X1.3) & 0.76 & 0.80 \\
\hline- & Responsibility (X1.4) & 0.85 & 0.93 \\
\hline- & Development (X1.5) & 0.80 & 0.83 \\
\hline - & Quality of leadership supervision (X1.6) & 0.76 & 0.80 \\
\hline - & Salary (X1.7) & 0.84 & 0.86 \\
\hline - & Organization Rules (X1.8) & 0.78 & 0.82 \\
\hline- & Physical conditions of work (X1.9) & 0.89 & 0.90 \\
\hline- & Working relationship (X1.10) & 0.89 & 0.90 \\
\hline & atisfaction (X2) & 0.86 & 0.96 \\
\hline- & Salary (X2.1) & 0.73 & 0.89 \\
\hline- & Promotion (X2.2) & 0.74 & 0.79 \\
\hline- & Supervision (X2.3) & 0.88 & 0.89 \\
\hline- & Fringe Benefits (X2.4) & 0.70 & 0.92 \\
\hline- & Reward (X2.5) & 0.84 & 0.88 \\
\hline- & Working Rules and Procedures (X2.6) & 0.83 & 0.86 \\
\hline- & Co-Workers (X2.7) & 0.79 & 0.82 \\
\hline- & Work (X2.8) & 0.67 & 0.73 \\
\hline- & Communication (X2.9) & 0.72 & 0.77 \\
\hline \multicolumn{2}{|c|}{ Commitment to change $(\mathrm{Y})$} & 0.96 & 0.96 \\
\hline- & Affective commitment (Y.1) & 0.79 & 0.96 \\
\hline- & Normative commitment (Y.2) & 0.76 & 0.79 \\
\hline - & Continuans commitment (Y.3) & 0.78 & 0.81 \\
\hline
\end{tabular}

The hypothesis assess by examining the coefficients path in the structural equation model. If the value of t-count $>1.96$ or $t$-count $<-1.96$ then it influence variables significantly

Table 5. SEM Model Result

\begin{tabular}{ccccccc}
\hline \multicolumn{2}{c}{ The effect of variable } & Koef. variable & t-count & Conclusion & Information \\
\hline H1: Motivation (X1) & $\rightarrow$ & Job Satisfaction (X2) & 0.99 & 5.77 & Significant & $\mathrm{H}_{1}$ Accepted \\
H2: Motivation (X1) & $\rightarrow$ & Commitment to change (Y) & -0.57 & -1.01 & No significant & $\mathrm{H}_{2}$ Rejected \\
H3: Job Satisfaction (X2) & $\rightarrow$ & Commitment to change (Y) & 1.28 & 2.30 & Significant & $\mathrm{H}_{3}$ Accepted \\
\hline
\end{tabular}

\section{Research Finding}

\subsection{Hypothesis 1 (H1) Motivation and Job Satisfaction}

The results of the hypothesis testing showed the coefficient variable of motivation on job satisfaction is 0.99 with 5.77 t-count. The t-count value is greater than 1.96, it means that motivation has a positive and significant effect on job satisfaction. therefore, the hypothesis which states that work motivation has a significant association with job satisfaction is accepted. It is in line with the research of Ayub and Rafif (2011), which stated that work motivation has a positive and significant effect on job satisfaction. Furthermore, the research of Karshli and Iskender (2009) revealed that the level of motivation has an effect on job satisfaction, hence the employees who are highly motivated will have high job satisfaction. 


\subsection{Hypothesis 2 (H2) Motivation and Commitment to Change}

The results of the hypothesis testing showed coefficients variable of motivation on change commitment is -0.57 with $-1.01 \mathrm{t}$-count. The $\mathrm{t}$-count value is smaller than 1.96, it means that motivation has a negative association and not significant with variable commitment to change. Thus, the hypothesis $(\mathrm{H} 2)$ that said that motivation has a significant effect on the commitment to change cannot be accepted. These results are not in line with the research of Parish et al. (2008) which states that motivation has a positive effect on commitment to change, especially affective commitment. Parish et al. (2008) research was conducted in the context of non-profit organizations, while this research was conducted in government organization, so there was differences in research respondents.

Elias (2007) found that motivation has an effect on affective commitment to change when mediated by the attitude on change variables. Individuals will be motivated internally if given the opportunity to find new things in their work and find personal goals in the organization's changes. According to Hultman (1988, in Mangundjaya 2016) there are four attitudes of individuals in dealing with change, namely: 1) willing and able to change, 2) not willing but able to change, 3) willing to but not able to change and 4) not willing to and not able to change.

\subsection{Hypothesis 3 (H3) Job Satisfaction and Commitment to Change}

The results of the last hypothesis testing showed the coefficient variable of job satisfaction with commitment to changes is 1.28 with 2.30 t-count. The t-count value is greater than 1.96 , it means that job satisfaction has a positive and significant effect on the commitment to change. Therefore, the hypothesis which states that job satisfaction significantly influences the commitment to change is accepted. These results reinforce the research of Yousef (1998), Mangundjaya (2015) and Wulandari (2015) that revealed job satisfaction has a positive and significant influence on the commitment to change. Furthermore, Yousef (2000) suggests that indicators of job satisfaction contribute to affective commitment to change, such as job satisfaction, salary and supervision of the leadership. Al-Swidi et al. (2012) explained that transformational leadership gives a positive influence toward the level of employees' job satisfaction.

\section{Discussion and Implication}

The results of the study indicated that SOE Ministry employee's motivation does not significantly influence the commitment to change, but the motivation of the SOE Ministry employees affected job satisfaction, while job satisfaction has a significant effect on the commitment to change. Quantitatively, things that make SOE Ministry motivated to work are because of the salary, the quality of leader supervision, and the relation with partner. It is also indicated that the source of SOE Ministry Employee's motivation was from hygene factors or extrinsic factors, and will cause inconvenience if they do not have it. Accordance with Herzberg Theory, extrinsict factor will not produce either motivation, or affective commitment to change. While, intrinsic factor will produce self-motivation to drive employee's affective commitment to change. Therefore the management division should establish the source of motivation that will generate motivation from inside (intrinsic), with the opportunity to excel, recognize by having working innovation, and have self-development programme that systemizes with employees' career management.

Regarding to employees' job satisfaction, quantitatively employees feel satisfied with the salary and benefits received because there is always a salary increase and performance allowances while employee also can get another income from other additional jobs. In addition, supervision quality and relationship with partner also provided job satisfaction. In other hand, there are factors related to promotion and working recognition system that shows dissatisfaction. The strategy that needs to be carried out by the SOE Ministry is to create a fair and transparent career management system based on the competency mapping and employee's performance.

Furthermore, employee commitment to change showed a tendency of normative and continuous commitment. Although employees were consciously and voluntarily wanted to support organizational change, employees feel obligated to support organizational change, and not taking the effective role to make changes to the organization. It is also confirmed through focus group discussion (FGD) that found the necessity to support the existence of organizational change. Based on interviews with management division, the approach that has been carried out so farabout organizational changes, in this case, it is the implementation of Bureaucratic Reformation in a Top-Down manner, from leaders and managers that trigger organizational changes, creating, implementing and monitor new regulations.

Some Strategies to increase commitment to change of SOE Ministry employee to support Bureaucratic Reformation and Organizational Transformation, are :

a. The embedded sense of urgency related to Bureaucratic Reformattion and Organizational Transformation not 
only because of the existence of rewards in the form of mere allowances. But, this sense of urgency will establish self-confidence about one's ability to achieve success (Bandura 1986, in Armenakis 2001).

b. Creating a cultural transformation in the organization with the help from the change agents who play an active role in communicating organizational changes in each division. Communication with employees related to transformational changes will be very helpful, so that in the transformational implementation phase, employee confidence, commitment, and willingness to participate can be developed (Smith, 2006).

c. The SOE Ministry management produced a fair and transparent career management policies, and also develop employee' recognition and developing systems. Fair and transparent human resource policy, will increase employee trust toward management. Thus, management will have an impact on employee' change commitment (Ghazali et al., 2008). It is supported by Kalyal and Saha (2008) research that stated that trust in management has a significant effect on employees' affective commitment to change.

d. The increasing commitment and role models from leaders to implement policies and the established systems will support the transformation. Abrell and Rowold (2014) stated that one form of transformational leadership is having a strong commitment and being a model of change will increase employee affective commitment to change. The enhancement in affective commitment is important because this affective commitment to change has a big impact on performance improvement, learning processes and the success of the changes themselves (Parish et al., 2008).

\section{References}

Abrell-Vogel, C., \& Rowold, J. (2014). Leader's Commitment to Change and their Effectiveness to Change-a multilevel investigation. Journal of Organization Change Management, 27(6), 900-921. https://doi.org/10.1108/JOCM-07-2012-0111

Al-Swidi, A. K., Nawawi, M. K. M., \& Al-Hosam, A. (2012). Is The Relationship Between Employees' Psychological Empowerment and Employees' Job Satisfaction Contingent on The Transformational Leadership? A Study on the Yemeni Islamic Banks. Asian Social Science, 8(10), 130-150. https://doi.org/10.5539/ass.v8n10p130

Armenakis, A. A., \& Harris, S. G. (2001). Crafting a change message to create transformational readiness. $\begin{array}{llll}\text { Journal of Organizational Change } & \text { Management, } & \text { 15(2), }\end{array}$ https://doi.org/10.1108/09534810210423080

Ayub, N., \& Rafif, S. (2011). The Relationship between Work Motivation and Job Satisfaction. Pakistan Business Review, 13(2), 332-347.

Cunningham, G. B. (2006). The Relationship among commitment to change, coping with change, turn over intentions. European Journal of Work and Organizational Psychology, 15(1), 29-45. https://doi.org/10.1080/13594320500418766

Davidson, J. (2005). Change Management. Jakarta: Prenada Media.

Elias, S. M. (2007). Employee Commitment in Times of Change: Assessing the Importance of attitudes toward Organizational Change. Journal of Management, 20(10), 1-17. https://doi.org/10.1177/0149206307308910

Ghazali, R., Ahmad, A., Uli, J., Suandi, T., \& Hassan, S. A. (2008). Commitment to Change among Managers in Selected Services Organization in Malaysia. The International Journal of the Humanities, 6(8), 123-134. https://doi.org/10.18848/1447-9508/CGP/v06i08/42519

Hair, J. F. J., Black, W. C., Babin, B, J., \& Anderson, R. E. (2014). Multivariate Data Analysis. Edinburg Gate: Pearson Education Limited.

Herscovitch, L., \& Meyer, J. P. (2002). Commitment to Organizational Change: Extension of a Three-Compontent Model. Journal of Applied Psychology, 87, 474-487. https://doi.org/10.10372/F0021-9010.87.3.474

Igbaria, M., Zinatelli, N., Cragg, P., \& Caveye, A. L. M. (1997). Personal Computing Acceptance Factors in Small Firms: A Structural Equation Model. MIS Quarterly, 279-302. https://doi.org/10.2307/249498

Kalyal, H. J., \& Saha, S. K. (2008). Factors Affecting to Organizational Change in a Public Sectors Organization. NUST Journal of Business and Economic, 1(1), 1-10. https://doi.org/10.12691/education-3-6-16

Karshli, M. D., \& Iskender, H. (2009). To examine the effect of the motivation provide by the administration on the job satisfaction of teachers and the institutional commitment. Procedia Social and Behavioral Science, (1), 2252-2257. https://doi.org/10.1016/j.sbspro.2009.01.396 
Kementerian BUMN. (2017a). Roadmap BUMN. Jakarta (ID): Kementerian BUMN.

Kementerian BUMN. (2017b). Laporan Kinerja Kementerian BUMN. Jakarta (ID): Kementerian BUMN.

Kotter, J. P. (2002). The Heart of Change. Boston: HBS Pr.

Mangundjaya, W. H. (2015). Predictors of Commitment to Change: Job satisfaction, Organizational Trust and Psychological Empowerment. Proceedings of the Second Asia-Pacific Conference on Global Business, Economics, Finance and Social Sciences (AP15Vietnam Conference).

Mangundjaya, W. H. (2016). Psikologi Dalam Perubahan Organisasi. PT Swasthi Adi Cita: Jakarta.

Parish, J. T., Cadwallader, S., \& Busch, P. (2008). Want to, need to, and ought to: Employee commitment to Organizational change. Journal of Organizational Change Management, 21(1), 32-52. https://doi.org/10.1108/09534810810847020

Robbins, S. P., \& Judge, T. A. (2013). Organizational Behavior. London: Pearson.

Shum, P., Bove, L., \& Auh, S. (2007). Employee's Affective Commitment to Change: The Key Successful CRM Implementation. European Journal of Marketing, 42(11/12), 1346-1371. https://doi.org/10.1108/03090560810903709

Smith, I. (2006). Continuing Profesional Development and Workplace-Communicating in Times of Change. Library Management, 27(1/2), 108-112. https://doi.org/10.1108/01435120610647992

Spector, P. E. (1997). Job Satisfaction: Application, Assessment Cause and Consequences. California: SAGE Publication.

Wulandari, P., Mangundjaya, W., \& Utoyo, D. B. (2015). Is Job Satisfaction a moderator or mediator on the Relationship between change leadership and commitment to change?. Procedia-Social Behavioral, (172), 104-111. https://doi.org/10.1016/j.sbspro.2015.01.342

Yousef, D. (1998). Satisfaction with job security as a predictor of organizational commitment and job performance in a multicultural environment. International Journal of Manpower, 19(3), 184-194. https://doi.org/10.1108/01437729810216694

Yousef, D. (2000). Organizational commitment and job satisfaction as predictors of attitudes toward organizational change in a non-western setting. Personnel Review, 29(5), 567-592. https://doi.org/10.1108/00483480010296401

\section{Copyrights}

Copyright for this article is retained by the author(s), with first publication rights granted to the journal.

This is an open-access article distributed under the terms and conditions of the Creative Commons Attribution license (http://creativecommons.org/licenses/by/4.0/). 